The successor to the journal Music Review, Nineteenth-Century Music Review aims to locate music within the widest possible framework of intellectual activity pertaining to the long nineteenth century (c.1789-1914). It particularly welcomes interdisciplinary scholarship that explores music within the context of other artistic and scientific discourses. Articles with fine visual or iconographic content are encouraged, as are those rich in musically illustrative material. Articles accepted for publication will reflect a diversity of critical viewpoints.

\title{
Contents of Volume 7, Issue 1
}

Articles

Philip V. Bohlman

Margaret Mehl

Julie McQuinn

Martin V. Clarke

Allan W. Atlas
Herder's Nineteenth Century

Japan's Early Twentieth-Century Violin Boom

The Medieval Leper Plagues Modern Paris:

Sylvio Lazzari's La Lépreuse

The Illingworth Moor Singers' Book:

A Snapshot of Methodist Music in the Early Nineteenth Century

Vaughan Williams's Songs of Travel:

A Note on the Structural Role of the Thematic Recollections in Songs 4 and 9

Book Reviews

CD Reviews

Published in association with the Centre for Nineteenth-Century Music, Durham University, UK

Cover illustration: Le Figaro (8 Feb. 1912).

\section{ASHGATE}

Ashgate Publishing Limited Wey Court East, Union Road, Farnham, Surrey, GU9 7PT, England www.ashgate.com 